\title{
Tutkija-kääntäjän katse kohdistuu saamelaiseen nykyrunouteen
}

Kaisa Ahvenjärvi: Päivitettyä perinnettä. Saamelaisen nykyrunouden saamelaiskuvastoja. Jyväskylä Studies in Humanities 318. University of Jyväskylä, Jyväskylä 2017. Julkaistu myös sähköisesti: https://jyx.jyu.fi/handle/123456789/54273.90 s. + artikkelit.

Kaisa Ahvenjärven väitöskirja on arvokas ja kauan odotettu kontribuutio sekä saamentutkimukseen että kirjallisuudentutkimukseen, niin "kotimaiseen" kuin ylirajaiseen. Kategorioita ajatellen joudutaan heti alkuun pulmaan. Suomen alueella eri kielillä kirjoitettua saamelaiskirjallisuutta pidetään kotimaisena kirjallisuutena, perinteisen luokittelun mukaan "kolmantena kotimaisena kirjallisuutena", kuten lukee väitöskirjan ensimmäisen artikkelin ensimmäisellä sivulla. Toisaalta "kotimaisuus" voi saamelaiskirjallisuuden yhteydessä kuulostaa vähän ironiselta, kun ajattelee, että moni saamelainen kokee olevansa kolonisoidun kansan jäsen ja että saamelaiskirjallisuus on lähtökohtaisesti ylirajaista sekä transnationaalisuuden että monikielisyyden mielessä: saamelaisia asuu neljän valtion alueella ja saamelaista kirjallisuutta kirjoitetaan eri saamen kielillä sekä kyseisten neljän valtion valtakielillä. Saamelaisen kirjallisuuden ylirajaisuus toteutuu myös sillä tavalla, että saamelaisessa taiteessa on vaikeaa puhua eri taiteiden välisistä rajoista (ks. esim. Gaski 2011).

Kaisa Ahvenjärven tutkimus ei pelkästään tunnista näitä vaikeuksia vaan lähtee tutkimaan ja problematisoimaan niitä lisää. Ahvenjärvi on jo pitkään tehnyt ansiokasta tutkimusta saamelaisesta kirjallisuudesta, varsinkin runoudesta, josta on viime aikoina taas tullut "saamelaisen kirjallisuuden ykköslaji" (s. 36). Ahvenjärvi on julkaissut aiheesta useita artikkeleita ja päätoimittanut - Sanna Valkosen kanssa - Pohjoisen tiede- ja kulttuurilehti AGONin saamelaisen nykytaiteen numeron (3/2014), jossa korostui saamelaisten taiteiden yhteen kietoutuminen. Ahvenjärvi on kuitenkin ollut myös tärkeä tekijä ja osa viimeaikaista ilmiötä eli paluuta taiteiden tutkimuksen eri oppialoihin länsimaisesta näkökulmasta perinteisemmässä mielessä. Tämä ilmiö voidaan tulkita seurauksena eri taiteiden ja medioiden repertuaarien laajenemista. Veli-Pekka Lehtolan sanoin on selvää, ettei saamelaisen nykytaiteen tutkija voi hallita kaikkea ja että "sektoriajattelu" on tullut "uudella tavalla ja uudessa kontekstissa ajankohtaiseksi" (ParenteČapková 2015, 16).

\section{Päivitettyä perinnettä kääntäjä-tutkijan position näkökulmasta}

Päivitettyä perinnettä on Ahvenjärven aikaisemman tutkimuksen hieno huipentuma. Kyseessä on artikkeliväitöskirja, joka koostuu kolmesta pohjustusluvusta ("Johdanto", "Saamelaisen runouden kenttä" ja "Teoreettiset lähtökohdat ja keskeiset käsitteet"), artikkelitiivistelmistä sekä vuosina 2012-2015 ilmestyneistä artikkeleista ja loppuyhteenvedosta. Kuten kaikki onnistuneet artikkeliväitöskirjat, on myös Ahvenjärven väitöstyö paljon enemmän kuin tutkimusartikkeleiden summa. Sen todistaa myös eri osien pituus: väitöskirjaa varten kirjoitettu, neljää artikkelia kehystävä teksti on yhtä pitkä ellei pidempi kuin tutkimusartikkeliosuus. Kolmessa 
ensimmäisessä luvussa tekijä johdattelee lukijaa saamelaisen kirjallisuuden tutkimukseen, sen suhteeseen saamentutkimukseen sekä alkuperäiskansojen tutkimukseen ja siihen liittyvään poliittisuuteen. Luvut sisältävät myös johdatuksen saamelaisen runouden kenttään ja kirjoittajan käyttämiin teoreettismetodologisiin lähtökohtiin. Nämä kolme lukua osoittavat Ahvenjärven asiantuntevuuden, ja niistä käy selvästi ilmi, että tekijä on seurannut saamentutkimusta pitkään ja on syvällisesti perehtynyt sekä kirjalliseen aineistoon että sitä koskeviin tieteellisiin ja julkisiin keskusteluihin.

Tutkimuksen pääkysymys on, "miten saamelaisuutta kuvataan ja konstruoidaan 19802000 luvulla julkaistussa saamelaisessa runoudessa?" (s. 23). Osakysymyksiksi nousevat seuraavat: "Miten nykyrunoudessa käytetään saamelaisuuteen perinteisesti liitettyjä aiheita ja kuvastoja sekä suullisen tradition elementtejä ja minkälaisia merkityksiä niihin kiinnitetään? Miten nämä aiheet ja kuvastot ovat muuttuneet ja miten niitä on purettu, uudistettu ja päivitetty? Miten saamelaisuuden sisäiset erot ja luokittelut näkyvät runoissa ja miten ne risteävät keskenään? - - minkälaisia alkuperäiskansakirjallisuuksille tyypillisiä piirteitä saamelaisessa runoudessa on luettavissa ja miten ne rakentavat saamelaisuutta?” (s. 23).

Erittäin kiinnostavaksi asiaksi nousee johdannossa kääntäjä-tutkijan positio, jota kirjoittaja pohtii alaluvussa 1.4. Kuten voin oman kokemukseni perusteella todeta, kääntäminen on keino perehtyä tekstiin kaikkein syvällisimmällä tavalla, syvemmin kuin lähiluvun tai analyysin keinoin. Kääntäminen (ja varsinkin runouden kääntäminen) edellyttää perusteltua tulkintaa ja pakottaa kääntäjää pohtimaan tekstiä monesta eri näkökulmasta, jotta hän pystyy tarvittaessa artikuloimaan ja puolustamaan omia ratkaisujaan. Kääntäjä-tutkija (vai pitäisikö joissakin yhteydessä puhua myös tutkija-kääntäjästä) on myös erittäin tietoinen kääntäjän vastuusta: kääntämiseen liittyvien ratkaisujen lisäksi kääntäjä vastaa siitä, millainen kirjallinen kaanon rakentuu kohdekielessä hänen käännöstensä perusteella. Saamelaisen kirjallisuuden yhteydessä tämä voi tarkoittaa esimerkiksi eri valtioiden valtakielillä kirjoitettujen tekstien mukaan ottamista tai toisaalta ehdotonta saamenkielistä linjaa, pohjoissaamen kanonisoidun aseman vakiinnuttamista tai toisaalta sen problematisointia, sekä paljon muuta. Kuten Ahvenjärvi (s. 24) itse sanoo, "[k]ääntämisellä on aina myös kielipoliittisia ulottuvuuksia lähtien siitä, minkä kielisiä tekstejä ylipäätään pidetään kääntämisen arvoisina”. Tämän kääntäjän vastuun tiedostaminen ja pohdinta tuntuu sitäkin tärkeämmältä, koska Ahvenjärveltä on juuri ilmestynyt palkittu Tuulisolmut - Valikoima saamelaista nykyrunoutta -antologia (Ahvenjärvi 2018a), johon sisältyy neljän Ahvenjärven tutkiman, 1960- ja 1970-luvulla syntyneen saamelaisrunoilijan (Hege Sirin, Sigbjørn Skådenin, Rawdna Carita Eiran ja Irene Larsenin) tekstejä. Mukana on pohjoissaamesta ja norjasta suomennettuja runoja ja kuten kääntäjä sanoo antologian esipuheessa (Ahvenjärvi 2018b, 9), "Tuulisolmut ei [...] ole kattava läpileikkaus saamelaisen nykyrunouden kentästä, van sukellus neljän runoilijan poetiikkaan ja tematiikkaan". Saamelaisesta runoudesta kiinnostuneilla on siis nyt ainutlaatuinen tilaisuus tutustua tutkijan tekemään käännösvalikoimaan sekä valikoiman runoilijoiden tekstejä käsittelevään väitöstutkimukseen.

En ole kompetentti arvostelemaan Ahvenjärven suomennoksia, mutta hänen kääntämisstrategioittensa pohdinta (s. 24-25) herättää positiivisia odotuksia. Ahvenjärvi pohtii kääntäjän ikuista dilemmaa, vieraannuttamisen ja kotouttamisen välistä tasapainoilua. Mainitsemiensa esimerkkien perusteella hän yrittää olla mahdollisimman "uskollinen alkutekstille" (s. 24), mikä voi tietenkin tarkoittaa montaa eri asiaa. Oman kääntämisfilosofiani perusteella pidän tärkeänä ja arvokkaana, ettei Ahvenjärvi kotouta liikaa niitä saamen kielen sanoja, joille ei löydy yhden sanan vastineita suomeksi. Tämä ratkaisu tuo mieleen kääntämisen politiikkaa koskevia 
keskusteluja Nils-Aslak Valkeapään Beaivi, áhčážan -teoksen yhteydessä (Rojola 2015, 88-89). Ahvenjärven vieraannuttavat ratkaisut kuulostavat hyvin harkituilta ja vaikuttavilta. Arvostan myös tekijän rehellisyyttä: hän tuo avoimesti esiin omia tulkinnallisia virheitään, joita tapahtuu jokaiselle kääntäjälle. Kääntäjä-tutkijan position etu on tässä yhteydessä se, että hän voi "korjata itseään" ja avata syyt valitsemiinsa ratkaisuihin (vrt. s. 26). Kaiken kaikkiaan olisin lukenut aiheesta mielelläni paljon enemmän, ainakin kokonaisen tutkimusartikkelin verran!

\section{Saamelaisen runouden kenttä, tutkittava aineisto ja teoreettismetodologisia lähtökohtia}

Väitöskirjan toinen luku, "Saamelaisen runouden kenttä", tarjoaa asiantuntevan ja systemaattisen, mutta samalla kaikkia valmiita kategorioita ja luokitteluja kyseenalaistavan johdatuksen asiaan. Ahvenjärvi tarjoaa katsauksen saamelaisen kirjallisuuden historioihin ja yleisesityksiin ja nostaa esiin saamelaisten rikkaan suullisen perinteen, varsinkin saamelaiselle nykyrunoudelle tärkeän joikurunouden. Sen merkitystä on syytä korostaa aina uudelleen, minkä osoittaa mm. Lea Rojolan (2018) Valkeapään joikuja käsittelevä artikkeli. Väitöskirjan lähtökohtiin ja peruskysymyksiin kuuluu saamelaiskirjallisuuden määritelmä. Saamelaisiin on viitattu yhtenäisenä ryhmänä, mikä on tietenkin harhaanjohtavaa, vaikka se onkin looginen seuraus metodologisesta nationalismista eli oletuksesta, että kirjallisuuden (sekä muun) tutkimuksen pitäisi kiinnittyä kansallisvaltioon tai ainakin johonkin yhteiseen ja yhtenäiseen identiteettiin perustuvan ryhmän viitekehykseen. Linda Hutcheon (2002) on puhunut "kansallisen kirjallisuushistorian mallista", jota on käytetty identiteettipolitiikkaan perustuvien ryhmien kirjallisuushistorian kirjoituksessa.

Ahvenjärvi avaa ansiokkaasti tämän kysymyksen kompleksisuuden ja kartoittaa jännitteitä saamelaisten sisäisten erojen ja yhteenkuuluvuuden tunteen välillä. Tutkijan saamelaisen kirjallisuuden määritelmä on suorassa kytköksessä hänen valitsemaansa aineistoon ja sen valintaprosessiin. Aineisto koostuu kahdeksan saamelaislyyrikon tuotannosta; mukana on pohjoissaameksi ja norjaksi kirjoittavia tekijöitä. He ovat Nils-Aslak Valkeapää (1943-2000), Rauni Magga-Lukkari (s. 1943), Inga Ravna Eira (s. 1943), Ellen Marie Vars (s. 1957), Inger-Mari Aikio (ent. Aikio-Arianaick, s. 1961), Irene Larsen (s. 1964), Rawdna Carita Eira (s. 1970) ja Hege Siri (s. 1973). Lisäksi Ahvenjärvi käsittelee artikkeleissaan lyhyesti myös kolmea muuta runoiljiaa, Aagot Vinterbo-Hohria (s. 1936), Rose-Marie Huuvaa (s. 1943) ja Risten Sokkia (s. 1954). Ahvenjärven kuvaama aineiston valintaprosessi kuvastaa sitä, miten kirjoittajan oma käsitys saamelaisesta kirjallisuudesta "on laajentuntut niin maantieteellisesti kuin kielellisestikin" (s. 20). Valitun aineiston perusteella hahmotettu saamelaiskirjallisuuden määritelmä ei tarkoita pelkästään ylirajaista vaan myös monikielistä kirjallisuutta. Aineistoon mahtuu useampi runoilijasukupolvi, niin klassikoita kuin nuoria runoilijoita. Kuten Ahvenjärvi korostaa, valinta on välttämättä subjektiivinen ja se perustuu tutkimuskysymyksiin ja niiden ohjaamiin tutkimusintresseihin.

Jo väitöskirjan tutkimuskysymyksestä ja sen osakysymyksistä voi päätellä, että kyseessä on kulttuurintutkimukselliseen otteeseen pohjautuva representaatiotutkimus, jota koskeville pohdinnoille on omistettu kolmannen luvun ensimmäinen alaluku. Ahvenjärvi käy dialogia sekä yleisten representaation teoretisointien että saamelaisrepresentaatioiden aikaisemman tutkimuksen kanssa - päärooleissa tässä ovat Veli-Pekka Lehtolan, Vuokko Hirvosen, Rauna Kuokkasen ja Sanna Valkosen tutkimukset, joihin tekijä nojaa monella tapaa. Ahvenjärvi 
nostaa esiin tärkeitä poliittisia kysymyksiä, joista monet ovat yhteisiä muillekin alkuperäiskansojen representaatiota koskeville debateille, mutta tekijä kontekstualisoi johdonmukaisesti jokaisen kysymyksen. Hän kohtaa suoraan myös ikuisen kysymyksen representaatioiden ja reaalimaailman välisestä suhteesta eikä yritä paeta sitä retorisin keinoin. Olli Löytyn (2006) tavoin Ahvenjärvi nimeää tulkittavien tekstien yhdeksi kontekstiksi reaalitodellisuuden, samoin kuin saamelaisyhteisöjä koskevan tutkimuksen, joka valaisee väitöskirjan kohdetekstejä. Tässäkin yhteydessä Ahvenjärvi on tietoinen omasta vallastaan ja vastuustaan, kun hän tutkijana käyttää "itsekin representaatioihin sisältyvää luokitteluvaltaa" (s. 48). Hän pohtii myös sitä, miten väitöskirjan tutkimuskysymys omalla tavallaan vahvistaa metodologisen nationalismin eli "yhden saamelaisuuden" oletusta esittämällä, että "saamelaisen kirjailijan tuotannossa oman etnisen tai kansallisen ryhmän kuvaamisella on merkittävä rooli” (s. 50). Samalla hän kuitenkin tuo esiin saamelaisuuden merkityksen etnopoliittisessa keskustelussa ja sen tärkeyden poliittisena ja emansipatorisena kategoriana (ibid.).

Eettisiä kysymyksiä pohditaan väitöskirjassa kiitettävän paljon ja syvällisesti. Ahvenjärvi tuo esiin oman roolinsa saamelaiskulttuurin ulkopuolisena tutkijana, joka tarkastelee kohdettaan ulkopuolisin silmin. Hän on hyvin tietoinen eettisiä valtakysymyksiä koskevista debateista, joihin ovat osallistuneet mm. Rauna Kuokkanen, Veli-Pekka Lehtola, Anni-Siiri Länsman ja Sanna Valkonen. Niissä on keskusteltu kulttuurisesta omimisesta sekä siitä, kenellä on valta puhua saamelaisyhteisön puolesta ja kuka tietää ja määrittelee, minkälainen tutkimus on relevanttia ja saamelaisen yhteisön tarpeita palvelevaa. Keskusteluissa on ollut esillä myös, miten tärkeää on, että saamelaiset osallistuvat itse tutkimusprosessiin käsitteellisen tiedon tuottajina. (Ks. esim. s. 52.)

\section{Jälkikolonialismi, alkuperäiskansatutkimus ja estetiikan ongelma}

Tutkimuksen tärkeänä kehyksenä on jälkikolonialistinen kirjallisuusteoria. Se on ollut pitkään mallina monille tutkimussuuntauksille, joissa keskitytään erilaisten toiseuksien ja niistä johtuvien valtadynamiikkojen tarkasteluun sekä identiteettipoliittisiin kysymyksiin. Jälkikolonialistinen ajattelu inspiroitui feministisestä kirjallisuudentutkimuksesta, ja se on myös inspiroinut feministisiä teoreetikkoja uusiin ajatuksiin.

Ahvenjärvi esittelee väitöskirjassaan feministisen tutkija Elaine Showalterin innoittamaa Robert Fraserin jälkikoloniaalisen kirjallisuuden kehitystä kuvaavaa jaottelua, johon nojataan ensimmäisessä tutkimusartikkelissa. Kyse on kirjallisen kehityksen periodisaatiosta, jota voi soveltaa eri ryhmien kirjallisuuksiin - naisten kirjoittamaan kirjallisuuteen tai jonkun (etnisen) ryhmän, kuten saamelaisten, kirjallisuuteen. Kehitys kulkee jäljittelystä protestin kautta oman äänen löytämiseen. Väitöskirjan toisessa luvussa Ahvenjärvi reflektoi mallin käyttökelpoisuutta ja toteaa, että hänen tapansa hyödyntää Fraserin "itsessään varsin yksioikoista mallia jää pintapuoliseksi kokeiluksi” (s. 32). Väitöskirjan ensimmäistä artikkelia lukiessa kuitenkin huomaa, että Ahvenjärvi käytti mallia jo silloin kriittisesti eikä rajannut tulkintojaan siihen. Väitöskirjaa kehystävissä luvuissa tekijä pohtii ja problematisoi jälkikolonialistisen metodologian soveltuvuutta saamelaiskirjallisuuden tutkimiseen yleisesti ja nostaa esiin sekä jälkikolonialististen teorioiden hyötyjä että niihin liittyviä ongelmia alkuperäiskansaa koskevassa tutkimuksessa.

Juuri saamelaisen kirjallisuuden, nimenomaan runouden, analyysi alkuperäiskansatutkimuksessa kehitettyjen metodien avulla on ollut Kaisa Ahvenjärven tutkimuksen tärkeää antia, 
ja se myös edistää hänen metodologiansa ylirajaisuutta (vrt. s. 51). Kuten Ahvenjärvi tuo esiin ensimmäisen väitöskirja-artikkelin loppuosiossa, jälkikoloniaalista teoriaa ei ole usein sovellettu runouden analyyseihin ja sellainen voi monipuolistaa tutkimussuuntauksen kysymyksenasetteluja.

Saamelaisuuden ja sen representaatioiden tutkimisen muiden alkuperäiskansojen kontekstissa voi nähdä lähtevän Nils Aslak Valkeapään roolista alkuperäiskansa-aktiivina, hänen kiinnostuksestaan muita alkuperäiskansoja kohtaan sekä hänen pyrkimyksistään korostaa saamelaisten asemaa alkuperäiskansana Pohjois-Euroopassa. Alkuperäiskansatutkimus - saamentutkimus mukaan lukien - hyödyntää jälkikolonialistisista teorioista tuttuja metodeja. Ahvenjärvi jatkaa Lehtolan tapaa lähteä liikkeelle joistakin jälkikolonialismin käsitteistä ja käyttää niitä kriittisesti, tarkkaan kontekstualisoiden. Alkuperäiskansatutkimuksessa on kuitenkin usein suhtauduttu jälkikolonialismiin melko kriittisesti. Ensinnäkin alkuperäiskansojen näkökulmasta kolonialismi jatkuu eikä jälkikolonialismi-termissä ole paljon järkeä - viime vuosikymmeninä on puhuttu paljon uuskolonialismista. Myös dekolonisaation käsite on alkuperäiskansatutkimuksen näkökulmasta ongelmallinen: se on tarkoittanut siirtomaavallan purkautumista ja siirtomaiden itsenäistymistä, mutta, Pekka Valtosen sanoin, monen "valtiottoman kansakunnan" eli ilman omaa valtiota edelleenkin olevan alkuperäiskansan tapauksessa tämä prosessi ei ole johtanut eikä ole johtamassa oman itsenäisen valtion perustamiseen. Toiseksi jälkistrukturalistisia teorioita hyödyntänyt jälkikolonialismi näyttäytyy länsimaisena ja näin ollen vieraana teoriana. Jälkikolonialistisissa teorioissa on usein purettu tai ainakin ohitettu kokemus "alkuperäisyydestä" (indigeneity), joka on koettu essentialistisena, kun taas alkuperäiskansatutkimuksessa se on ollut oleellinen käsite. Debatit muistuttavat feministisen tutkimuksen yhteydessä käytyjä keskusteluja ja Ahvenjärvi näyttää, miten tärkeä voi alkuperäiskansatutkimuksen yhteydessä olla Gayatri Chakravorty Spivakin ajatus strategisesta essentialismista eli siitä, että yhteisten poliittisten päämäärien saavuttamisessa on tärkeää omaksua ja ylläpitää yhtenäinen ryhmäidentiteetti, jonka merkeissä häivytetään sisäiset erot. Tässä korostuu - taas kerran - feministisen tutkimuksen tärkeys 1900-luvun viimeisten vuosikymmenien identiteettipolitiikkaan perustuville tutkimussuuntauksille.

Strategiseen essentialismiin liittyvien identiteettikeskustelujen ajankohtaisuuteen kytkeytyvät myös Ahvenjärven käyttämät kuulumisen (belonging) ja ei-kuulumisen (non-belonging) käsitteet. Kuulumisen ajatuksessa yhtyvät hyvin henkilökohtainen kaipuu kuulumiseen (longing to belong) ja kuulumisen politiikka (politics of belonging). Samantyyppisiä mekanismeja voi tutkia eri teoreettisissa kehyksissä esim. identifikaation eli samastumisen (identification) käsitteen, varsinkin ryhmäidentiteetteihin johtuvien identifikaatioiden, avulla (ks. esim. Laplanche 1976). Lisää näkökulmia asiaan voisivat tuoda Jürgen Habermasin (1998) ajatuksista lähtevät poissulkemisen käsitteet inclusion ja exclusion.

Kuulumisen käsitettä on hyödynnetty myös luokkatutkimuksessa ja yhteiskunnallista nousua kuvaavien representaatioiden tarkastelussa, joissa on pääroolissa juuri kysymys identiteetistä (esim. Sasson 2012). Näin peliin astuu kokonainen kirjo yhteiskunnallisia kategorioita, jotka tuottavat eroja - luokan, etnisyyden, kansallisuuden, kielellisen identiteetin ja sukupuolen lisäksi muun muassa myös seksuaalisuus, uskonto, terveydentila ja ikä. Näiden erojen luomia hierarkioita ja niistä johtuvaa valtadynamiikkaa tutkii intersektionaalinen lähestymistapa. Kuten Ahvenjärvi (s. 59) huomauttaa, paljon intersektionaalista tutkimusta on tehty käyttämättä kyseistä termiä, kuten osoittavat esimerkiksi Lehtolan kirjoitukset. Ahvenjärvi pohtii ensisijaisesti sukupuolen ja entisyyden roolia, mutta myös kielellinen identiteetti ja siihen liittyvät hierarkiat 
ja valtadynamiikat nousevat esiin varsinkin viimeisissä väitöskirja-artikkeleissa. Edellä mainittujen käsitteiden (identifikaatio, inclusion/exclusion) käyttö olisi voinut rikastuttaa Ahvenjärven analyyseissa käytettyä intersektionaalista metodia ja tuoda tulkintoihin lisää vivahteita.

Alkuperäiskansatutkimuksessa on koettu haasteelliseksi myös länsimainen esteettinen kriteeristö. Sen merkeissä on usein väheksytty alkuperäiskansojen kirjallisuutta, koska se perustuu erilaisiin perinteisiin eikä vastaa länsimaisen lukijan esteettistä odotushorisonttia. Ahvenjärvi viittaa Vuokko Hirvosen, Rauna Kuokkasen ja Kristin Jernslettenin tutkimuksiin, jotka analysoivat näitä saamelaistaiteen arvottamisen ongelmia ja kehittävät (varsinkin Jernsletten) saamelaista metodologiaa. Tämä on erittäin tärkeä ja jatkuvasti edistyvä suunta. Saamelaisen runouden analyysi länsimaisen poetiikan hengessä on selvästi hyvin ongelmallinen lähestymistapa, mutta jos länsimaisilla käsitteillä operoi hienovaraisesti, kunnioittaen alkuperäiskansan runoilijan omia lähtökohtia ja kontekstia, pääsee laajentamaan edellä mainittua länsimaisen lukijan odotushorisonttia. Sen osoittaa esimerkiksi Karoliina Lummaan (2007, 59-61) aamun topoksen analyysi yhdessä Nils Aslak Valkeapään runossa.

Ahvenjärven väitöskirjaan olisin kaivannut tällaisen analyysin mahdollisuutta käsittelevää syvällisempää teoreettista pohdintaa, jossa tarkasteltaisiin mahdollisuuksia hyödyntää sekä länsimaisia analyysin ja tulkinnan välineitä että saamelaiseen metodologiaan perustuvaa lähestymistapaa. Tämä ei olisi mahtunut Ahvenjärven representaatiotutkimukseen, mutta toivottavasti tutkija innostuu sen pariin joskus myöhemmin. Hän voisi jatkaa kohdasta, missä itse korostaa, että väitöstutkimuksessa sai eniten tilaa Irene Larsenin kokoelma Sortsolsafari, joka "noudattelee monella tapaa 'länsimaista' estetiikkaa" ja "avautuu luontevasti 'länsimaiselle' akateemiselle luennalle" (s. 22). Tällainen ote kytkeytyisi hienosti vastaanottokysymyksiin, joihin Ahvenjärvi aikoo keskittyä (ks. s. 73).

\section{Lopuksi}

Ahvenjärven edellä mainittua Larsenin kokoelmaa käsittelevää artikkelia pidän väitöskirjan parhaimpana. Tekijä on siinä onnistunut problematisoimaan kysymyksen saamelaisesta identiteetistä monella eri tasolla ja valaisemaan sitä monesta näkökulmasta. Larsenin kokoelman melankolisten, parodisten, nostalgisten ja ironisten sävyjen erittely on antanut Ahvenjärvelle mahdollisuuden erittäin oivaltavaan ja hienovaraiseen analyysiin ja tulkintaan. Ei tunnu ollenkaan siltä, että tutkimuskysymykset olisivat "tuottaneet niihin enemmän tai vähemmän sopivat vastaukset" (vrt. s. 68), kuten tekijä itsekriittisesti huomauttaa yhteenvedossaan.

On ilahduttavaa, että saamelaista runoutta on viime vuosina tutkittu suomalaisessa kirjallisuudentutkimuksessa erilaisista innovatiivisista, muun muassa ekokriittisistä (Hanna Mattila) ja posthumanistisista (Lea Rojola), lähtökohdista. Tutkimuskohteena ovat olleet - ja ovat edelleen - enimmäkseen Nils-Aslak Valkeapään tekstit. Valkeapään merkitystä saamelaiselle runoudelle, taiteelle sekä koko saamelaiskysymykselle ei voi tarpeeksi korostaa, kuten osoittaa Valkeapään elämäntyölle omistettu Minä soin / Mun čuojan -niminen tutkimusantologia, joka ilmestyi samana vuonna kuin Päivitettyä perinnettä. On kuitenkin merkittävää, että Kaisa Ahvenjärven ansiosta nousee esiin kahden kirjan verran myös saamelaisten nykynaisrunoilijoiden tuotantoa. Sopii toivoa, että edellä mainittujen estetiikkaan ja vastaanottoon liittyvien kysymysten lisäksi tekijä syventää, suunnitelmiensa mukaan (vrt. s. 71), myös vertailevaa otetta alkuperäiskansatutkimukseen liittyvässä pohdinnassaan. Myös "vertailevan katseen suunnistaminen 
maantieteellisesti lähemmäs" kuulostaa tärkeältä. Olisi mainiota, jos katse suuntautuisi jatkossa myös Venäjällä asuviin saamelaiskirjailijoihin.

\author{
Viola PARENTE-ČAPKová \\ viocap@utu.fi \\ Kotimainen kirjallisuus \\ 20014 Turun yliopisto
}

\title{
Lähteet
}

AhVenjärvi, KaISA 2018a: Tuulisolmut - Valikoima saamelaista nykyrunoutta. Poesia, Helsinki.

2018b: Esipuhe. Kaisa Ahvenjärvi (toim. ja suom.): Tuulisolmut - Valikoima saamelaista nykyrunoutta. Poesia, Helsinki.

Ahvenjärvi, Kaisa ja Valonen, Sanna 2014 (toim.): AGON. Pohjoinen tiede- ja kulttuurilehti 3/2014. Saamelainen nykytaide. Saatavissa http://agon.fi/arkisto/numero/?issue=2014-3

GASKI, HARALD 2011: Song, poetry and images in writing: Sami literature. KAREN LANNGÅRD ja KirsTEN THISTED (toim.): From oral tradition to rap. Literatures of the Polar North, 15-38. Ilisimatusarkif / Forlaget Atuagkat, Nuuk. https://doi.org/10.7557/13.1804

Habermas, Jürgen 1998: The inclusion of the other: Studies in political theory. The MIT Press, Cambridge (MA).

Hutcheon, Linda 2002: Rethinking the national model. Linda Hutcheon ja Mario Valdés (toim.): Rethinking literary history. A dialogue on theory, 3-49. Oxford University Press, Oxford - New York.

LaPlAnChe, JeAn 1976: Life and death in psychoanalysis. The John Hopkins University Press, Baltimore MD.

LummaA, Karolinna 2007: Aihe, motiivi, teema ja topos. Miksi runossa kuvataan kukkaa? SIRU KaINULainen, Kaisu Kesonen ja Karolinna LummaA (toim.): Lentävä hevonen. Välineitä runoanalyysiin, 41-65. Vastapaino, Tampere.

LÖYtTY, Olli 2006: Ambomaamme. Suomalaisen lähetyskirjallisuuden me ja muut. Vastapaino, Tampere.

PARENTE-ČAPKOvá, VIOLA 2015: Kirjallisuudentutkimuksen asema saamentutkimuksessa ennen ja nyt - Keskustelua Veli-Pekka Lehtolan kanssa. Viola Parente-Čapková ja Kati Launis (toim): Kirjallisuudentutkimuksen aikakauslehti AVAIN 3/2015, 13-18. Saamelaisuus kirjallisuudessa. Saatavissa http://pro.tsv.fi/skts/Avain2015_3_sisalto.pdf. https://doi.org/10.30665/av.74991

Rojola, LEA 2015: ... sukkajalka, kalppinokka, tuuliturpa... Nils-Aslak Valkeapään porojen poetiikka. Viola Parente-Čapková ja Kati Launis (toim): Kirjallisuudentutkimuksen aikakauslehti AVAIN 3/2015, 86-104. Saamelaisuus kirjallisuudessa. Saatavissa http://pro.tsv.fi/skts/ Avain2015_3_sisalto.pdf. https://doi.org/10.30665/av.74996

2018: Juoigamat. Joiku Nils-Aslak Valkeapään runoudessa. SiRU KaInUlainen, LiISA STEINBY ja SusanNa VÄLımäKI (toim.): Kirjallisuuden ja musiikin leikkauspintoja, 387-413. Suomalaisen Kirjallisuuden Seura, Helsinki.

SASSON, SARAH JULIETTE 2012: Longing to belong: The parvenu in nineteenth-century French and German literature. Palgrave Macmillan, New York. Saatavissa https://doi.org/10.1057/9781137330819_2

Valtonen, Taarna ja Valkeapä̈̈, Leena (toim.) 2017: Minä soin. Mun čuojan. Kirjoituksia Nils-Aslak Valkeapään elämäntyöstä. Lapland University Press, Rovaniemi. 